\title{
Anti-cancer effects of newly developed chemotherapeutic agent, glycoconjugated palladium (II) complex, against cisplatin-resistant gastric cancer cells
}

Mamoru Tanaka ${ }^{1}$, Hiromi Kataoka ${ }^{1 *}$, Shigenobu Yano ${ }^{2,3}$, Hiromi Ohi ${ }^{4}$, Keisuke Kawamoto ${ }^{5}$, Takashi Shibahara ${ }^{5}$, Tsutomu Mizoshita ${ }^{1}$, Yoshinori Mori ${ }^{1}$, Satoshi Tanida' ${ }^{1}$ Takeshi Kamiya ${ }^{1}$ and Takashi Joh ${ }^{1}$

\begin{abstract}
Background: Cisplatin (CDDP) is the most frequently used chemotherapeutic agent for various types of advanced cancer, including gastric cancer. However, almost all cancer cells acquire resistance against CDDP, and this phenomenon adversely affects prognosis. Thus, new chemotherapeutic agents that can overcome the CDDP-resistant cancer cells will improve the survival of advanced cancer patients.

Methods: We synthesized new glycoconjugated platinum (II) and palladium (II) complexes, $\left[\mathrm{PtCl}_{2}\right.$ (L)] and $\left[\mathrm{PdCl}_{2}(\mathrm{~L})\right]$. CDDP-resistant gastric cancer cell lines were established by continuous exposure to CDDP, and gene expression in the CDDP-resistant gastric cancer cells was analyzed. The cytotoxicity and apoptosis induced by $\left[\mathrm{PtCl}_{2}(\mathrm{~L})\right]$ and $\left[\mathrm{PdCl}_{2}(\mathrm{~L})\right]$ in CDDP-sensitive and CDDP-resistant gastric cancer cells were evaluated. DNA doublestrand breaks by drugs were assessed by evaluating phosphorylated histone H2AX. Xenograft tumor mouse models were established and antitumor effects were also examined in vivo.

Results: CDDP-resistant gastric cancer cells exhibit ABCB1 and CDKN2A gene up-regulation, as compared with CDDP-sensitive gastric cancer cells. In the analyses of CDDP-resistant gastric cancer cells, $\left[\mathrm{PdCl}_{2}(\mathrm{~L})\right]$ overcame cross-resistance to CDDP in vitro and in vivo. $\left[\mathrm{PdCl}_{2}(\mathrm{~L})\right]$ induced DNA double-strand breaks.
\end{abstract}

Conclusion: These results indicate that $\left[\mathrm{PdCl}_{2}(\mathrm{~L})\right]$ is a potent chemotherapeutic agent for CDDP-resistant gastric cancer and may have clinical applications.

Keywords: Glycoconjugated platinum (II) complex, Glycoconjugated palladium (II) complex, Cisplatin, Drug resistance, Gastric cancer

\section{Background}

Cancer is a leading cause of death worldwide, and according to the WHO mortality database (as at November 2006), gastric cancer is the second leading cause of cancer death after lung cancer.

Cisplatin (CDDP) is the most frequently used chemotherapeutic agent for various types of advanced cancer and is used in combination regimens. Some CDDP-

\footnotetext{
* Correspondence: hkataoka@med.nagoya-cu.ac.jp

'Departments of Gastroenterology and Metabolism, Nagoya City University Graduate School of Medical Sciences, Kawasumi, Mizuho-cho, Mizuho-ku 467-8601, Nagoya, Japan

Full list of author information is available at the end of the article
}

based combination chemotherapy regimens have also shown high response rates [1]. Based on recent Japanese phase III trials for metastatic gastric cancer, S1 plus cisplatin combination chemotherapy was established as the standard first-line chemotherapy [2].

However, CDDP-based combination chemotherapy regimens have several disadvantages, including side effects such as nephrotoxicity, neurotoxicity, ototoxicity and vomiting. In addition, some tumors acquire resistance to CDDP, reducing its efficacy [3,4]. Several mechanisms are involved in CDDP resistance [5]. Such mechanisms include decreased intracellular drug accumulation and/or increased drug efflux [6-9], drug inactivation

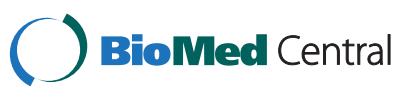


by increased levels of cellular thiols $[6,10]$, increased nucleotide excision-repair activity $[9,11]$ and evasion of apoptosis [6,12]. Thus, for continued progress in cancer therapy, more effective drugs must be found.

Cancer cells take in higher levels of glucose than normal cells, a phenomenon known as the Warburg effect [13]. To achieve lower undesired toxicity, enhanced solubility and tumor selectivity, we have developed and have reported several glycoconjugated drugs $[14,15]$. Another strategy to design new antitumor agents related to CDDP is to change the nature of the central metal ion $[16,17]$. As palladium (Pd) chemistry is similar to that of platinum (Pt), Pd complexes (II) are expected to exhibit antitumor activities similar to those of Pt. Attempts have been made to synthesize Pd (II) complexes with such activities, as Pd complexes are expected to have less kidney toxicity than Pt complexes [18].

In this study, we synthesized a new glycoconjugated Pt (II) complex and a new glycoconjugated Pd (II) complex, and analyzed its cytotoxicity, ability to induce apoptosis, and ability to induce DNA double-strand breaks in CDDP-sensitive and CDDP-resistant gastric cancer cell lines in vitro and in vivo.

\section{Methods \\ Drugs}

Reagents and solvents used in this study were commercial products of the highest available purity. The Pt (II) and Pd (II) complexes were easily prepared using the one-pot reaction of Pt (II) or Pd (II) salt, amino sugar and pyridine aldehyde derivative without isolation of a Schiff base ligand (L) as follows.

$\left[\mathrm{PtCl}_{2} \quad(\mathrm{~L})\right] \quad(\mathrm{L}=2$-deoxy-2-[(2-pyridinylmethylene) amino]- $\alpha$-D-glucopyranose):Dichloro (2-deoxy-2-[(2pyridinylmethylene)amino]- $\alpha$-D-glucopyranose) Pt. An aqueous $(50 \mathrm{~mL})$ solution of $\mathrm{D}(+)$-glucosamine - hydrochloride $(0.65 \mathrm{~g}, 3.0 \mathrm{mmol})$ was neutralized with $\mathrm{NaHCO}_{3}$ $(0.26 \mathrm{~g}, 3.1 \mathrm{mmol})$. To this solution, a $\mathrm{MeOH}(50 \mathrm{~mL})$ solution of 2-pyridinecarbaldehyde $(0.32 \mathrm{~g}, 3.1 \mathrm{mmol})$ was added, followed by stirring for $2 \mathrm{~h}$ and addition of $\mathrm{K}_{2}$ $\left[\mathrm{PtCl}_{4}\right](1.25 \mathrm{~g}, 3.0 \mathrm{mmol})$ in $30 \mathrm{~mL}$ of $\mathrm{H}_{2} \mathrm{O}$. The reaction was continued for another $41 \mathrm{~h}$ at room temperature. The mixture was concentrated by evaporation and the resulting residue was purified by silica gel column chromatography (eluent: acetone) to give a pale yellow powder $(1.07 \mathrm{~g}, 67 \%)$. Single crystals were obtained by recrystallization from $\mathrm{MeOH} / \mathrm{Et}_{2} \mathrm{O}$. Anal. calcd for $\left[\mathrm{PtCl}_{2}(\mathrm{~L})\right]$, $\mathrm{C}_{12} \mathrm{H}_{18} \mathrm{Cl}_{2} \mathrm{~N}_{2} \mathrm{O}$ Pt, C; 26.98, $\mathrm{H} ; 3.02$, N; 5.24. found for C; 27.13, H; 2.97, N; 5.07. MS (FAB, pos): $m / z=498[\mathrm{M}-\mathrm{Cl}]^{+}$.

$\left[\begin{array}{ll}\mathrm{PdCl}_{2} & (\mathrm{~L})] \quad(\mathrm{L}=2 \text {-deoxy-2-[(2-pyridinylmethylene) }\end{array}\right.$ amino]- $\alpha$-D-glucopyranose):Dichloro (2-deoxy-2-[(2pyridinylmethylene)amino]- $\alpha$-D-glucopyranose) palladium. This complex was prepared by following a similar procedure as described above for $\left[\mathrm{PtCl}_{2}(\mathrm{~L})\right]$ using $\mathrm{Na}_{2}\left[\mathrm{PdCl}_{4}\right]$ instead of $\mathrm{K}_{2}\left[\mathrm{PtCl}_{4}\right]$. The complex was dissolved in $\mathrm{MeOH}$ and insoluble materials were removed by filtration. The filtrate was concentrated by evaporation to give a pale yellow powder $(1.1 \mathrm{~g}, 83 \%)$. This complex was purified by recrystallization from $\mathrm{MeOH} / \mathrm{Et}_{2} \mathrm{O}$. Anal. calcd for $\left[\mathrm{PtCl}_{2}\right.$ (L)], $\mathrm{C}_{12} \mathrm{H}_{18} \mathrm{Cl}_{2} \mathrm{~N}_{2} \mathrm{O}_{5} \mathrm{Pd}, \mathrm{C} ; 32.35, \mathrm{H} ; 3.62$, $\mathrm{N} ;$ 6.29. found for $\mathrm{C} ; 32.02, \mathrm{H} ; 3.51, \mathrm{~N} ; 6.01$. MS (FAB, pos): $m / z=431[\mathrm{M}-\mathrm{HCl}+\mathrm{Na}]^{+}$.

CDDP and CBDCA were purchased from BristolMyers Co. (Tokyo, Japan). L-OHP was purchased from Yakult (Tokyo, Japan).

\section{Measurements}

Elemental analysis was carried out on a Perkin-Elmer $240 \mathrm{C}$ or a Fisons Instruments EA1108 Elemental Analyzer. ${ }^{1} \mathrm{H}$ - and ${ }^{13} \mathrm{C}$-NMR spectra were recorded on a JEOL JNM-GSX400 in N,N-dimethylformamide-d d $_{7}\left(\right.$ DMF- $\left.\mathrm{d}_{7}\right) /$ $\mathrm{D}_{2} \mathrm{O}$. Mass spectra were obtained on a JEOL JMS-700 T Tandem MS-station mass spectrometer.

\section{Crystallography}

Suitable crystals for X-ray crystallography were obtained by slow recrystallization of $\left[\mathrm{PtCl}_{2}(\mathrm{~L})\right]$ and $\left[\mathrm{PdCl}_{2}(\mathrm{~L})\right]$ from a minimal amount of methanol and ether mixtures. Crystallographic data (excluding structure factors) for the structure reported in this paper were deposited with the Cambridge Crystallographic Data Center as supplementary publication no. CCDC-835397. Copies of the data can be obtained free of charge on application to CCDC, 12 Union Road, Cambridge CB21EZ, UK (Fax: (+44) 1223-336-033; E-mail: deposit@ccdc.cam.ac.uk).

\section{Cell culture}

The human gastric cancer cell lines MKN28 (Japanese Cancer Research Resources Bank, No. 0253) and MKN45 (Japanese Cancer Research Bank, No. 0254) were cultured in RPMI1640 (Sigma-Aldrich, St. Louis, MO) supplemented with $10 \%$ fetal bovine serum (FBS) and 1\% ampicillin and streptomycin. Cells were cultured under an atmosphere of $5 \% \mathrm{CO}_{2}$ at $37^{\circ} \mathrm{C}$.

\section{Establishment of CDDP-resistant sublines from MKN28 and MKN45}

CDDP-resistant MKN28 (MKN28 (CDDP)) and CDDPresistant MKN45 (MKN45 (CDDP)) were established by continuous exposure to $\mathrm{CDDP}$ starting at $0.5 \mu \mathrm{mol} / \mathrm{L}$ and increasing in a stepwise manner to $10 \mu \mathrm{mol} / \mathrm{L}$ for more than 5 months. Experiments with these sublines were performed after maintenance in CDDP-free medium for 2-3 weeks. 


\section{RT2 Profiler PCR arrays for human cancer drug resistance \& metabolism}

Total RNA $(1 \mu \mathrm{g})$ from MKN45 (0) or MKN45 (CDDP) was converted to cDNA and used to screen inflammatory cytokines and receptors using quantitative real-time PCR arrays according to the manufacturer's instructions (SuperArray Bioscience). Reactions were cycled in an ABI Prism 7500 FAST sequence detector (Applied Biosystems) and acquired data were analyzed using the DDCt method to determine the expression levels of each transcript normalized against the expression level of housekeeping gene controls. A gene-wise, two-sample $t$-test was performed for each transcript to identify statistical differences in expression between MKN45 (0) or MKN45 (CDDP).

\section{In vitro treatment}

Cell viability was determined by WST- 8 cell proliferation assay. Gastric cancer cells were seeded into 96-well culture plates at $5 \times 10^{3}$ cells $/ 100 \mu \mathrm{L} /$ well and incubated overnight. Cells were treated for $48 \mathrm{~h}$ with graded concentrations of CDDP $(0-200 \mu \mathrm{mol} / \mathrm{L}), \quad\left[\mathrm{PtCl}_{2}(\mathrm{~L})\right]$ $(0-200 \mu \mathrm{mol} / \mathrm{L}), \quad\left[\mathrm{PdCl}_{2}(\mathrm{~L})\right] \quad(0-200 \mu \mathrm{mol} / \mathrm{L}), \quad \mathrm{L}-\mathrm{OHP}$ $(0-100 \mu \mathrm{mol} / \mathrm{L})$ or CABDA $(0-400 \mu \mathrm{mol} / \mathrm{L})$. After treatment, cells were incubated with cell a counting kit-8 (Dojindo, Kumamoto, Japan) for $4 \mathrm{~h}$ and absorption at $450 \mathrm{~nm}$ was measured with a microscope reader (SPECTRA MAX340; Molecular Devices, Silicon Valley, CA). Cell viability was expressed as a percentage vs. untreated control cells and half maximal (50\%) inhibitory concentration $\left(\mathrm{IC}_{50}\right)$ was calculated. Resistance factor (RF) is defined as the relative ratio of $\mathrm{IC}_{50}$ values in both cell lines (MKN28 (CDDP)/MKN28 (0) or MKN45 (CDDP)/ MKN45 (0)).

\section{Assessment of apoptosis}

Apoptosis was assessed by analysis of activation of caspase-3 and caspase-7 using the substrate DEVDaminoluciferin from the Caspase-Glo 3/7 Assay kit (Promega) according to the manufacturer's instructions. Briefly, gastric cancer cells $\left(10^{4}\right.$ per well) were plated on a 96-well culture plate with three replicates per treatment. After $24 \mathrm{~h}$ of plating, cells were treated for $72 \mathrm{~h}$ with graded concentrations of CDDP $(0-200 \mu \mathrm{mol} / \mathrm{L}),\left[\mathrm{PtCl}_{2}\right.$ (L)] $(0-200 \mu \mathrm{mol} / \mathrm{L}),\left[\mathrm{PdCl}_{2}(\mathrm{~L})\right](0-200 \mu \mathrm{mol} / \mathrm{L}), \mathrm{L}-\mathrm{OHP}$ $(0-100 \mu \mathrm{mol} / \mathrm{L})$ or CABDA $(0-400 \mu \mathrm{mol} / \mathrm{L})$. Caspase-Glo reagent was added to each well and incubated for $1 \mathrm{~h}$, and luminescence was measured using a LUMAT LB 9507 luminometer (Berthold Technologies). Results were analyzed by Welch's $t$-test between MKN45 (0) and MKN45 (CDDP).

\section{Assessment of DNA double-strand breaks}

Cells were washed with PBS (-) and subsequently dissolved in 1 cell lysis buffer (Cell Signaling Technology) containing $20 \mathrm{mmol} / \mathrm{L}$ Tris- $\mathrm{HCl}$ (pH 7.5), $150 \mathrm{mmol} / \mathrm{L}$ $\mathrm{NaCl}, 1 \mathrm{mmol} / \mathrm{L} \mathrm{Na2EDTA,} 1 \mathrm{mmol} / \mathrm{L}$ EGTA, 1\% Triton, $2.5 \mathrm{mmol} / \mathrm{L}$ sodium pyrophosphate, $1 \mathrm{mmol} / \mathrm{L}$ h-glycerophosphate, $1 \mathrm{mmol} / \mathrm{L} \mathrm{Na} 3 \mathrm{VO} 4$, and $1 \mathrm{Ag} / \mathrm{mL}$ leupeptin with the addition of $1 \mathrm{mmol} / \mathrm{L}$ phenylmethylsulfonyl fluoride. After disruption in an ice bath using a Bio-ruptor sonicator (Cosmo Bio) for $15 \mathrm{~s}$, lysates were centrifuged at $15,000 \mathrm{rpm}$ for $10 \mathrm{~min}$ at $4^{\circ} \mathrm{C}$. Each sample was normalized as equal protein concentrations using a protein assay kit (Bio-Rad Laboratories). An equal quantity of 2 SDS-PAGE sample buffer [0.5 mol/L Tris- $\mathrm{HCl}$ (pH 7.2), 1\% SDS, $100 \mathrm{mmol} / \mathrm{L} \beta$-mercaptoethanol, and $0.01 \%$ bromophenol blue] was added to each sample, followed by boiling for $5 \mathrm{~min}$ at $100^{\circ} \mathrm{C}$. Aliquots of sample were fractioned on $8 \%$ to $15 \%$ SDSPAGE and were then electroblotted onto nitrocellulose membrane. The membrane was blocked with 5\% skimmed milk in PBS (-) for $1 \mathrm{~h}$ at room temperature. The membrane was incubated with primary antibodies, anti$\gamma \mathrm{H} 2 \mathrm{AX}$ (Bethyl Laboratories, Inc., 1:2000), overnight at $4^{\circ} \mathrm{C}$ and was then washed with $0.05 \%$ Tween 20 in PBS (-) three times at 5-min intervals. The membrane was incubated with secondary antibody for $1 \mathrm{~h}$ at room temperature followed by three washes with $0.05 \%$ Tween 20 in PBS (-) three times at 5-min intervals. The membrane was treated with enhanced chemiluminescence detection reagents (Amersham) for $1 \mathrm{~min}$ at room temperature and exposed to scientific imaging films (Eastman Kodak), and proteins were visualized as bands. Filters were stripped and re-probed with monoclonal $\beta$-actin antibody (Abcam plc) as an internal control.

\section{Animals and tumor models}

Pathogen-free female nude mice (BALB/c Slc-nu/nu) aged 4 weeks and weighing 20-25 g were obtained from Japan SLC (Kyoto, Japan). Animals were allowed to acclimatize for 2 weeks in the animal facility before any interventions were initiated. Xenograft tumor models were established by subcutaneously implanting $3 \times 10^{6}$ gastric cancer cells (MKN45 (0), MKN45 (CDDP)) in $200 \mu \mathrm{L}$ of PBS. Experimental procedures were approved by the Nagoya City University Center for Experimental Animal Science, and mice were raised in accordance with the guideline of the Nagoya City University Center for Animal Experiments.

\section{In vivo treatment}

At 7 days after tumor inoculation, mice were given an intraperitoneal injection of CDDP, $\left[\mathrm{PtCl}_{2}(\mathrm{~L})\right]$ or $\left[\mathrm{PdCl}_{2}\right.$ (L)] at a dose of $40 \mu \mathrm{mol} / \mathrm{kg}$. Tumor growth was monitored daily by measuring tumor volume with vernier calipers. Tumor volume was calculated using the following formula: (length $\times$ width $\times$ depth)/2. Each group 
consisted of 5 mice. Results were analyzed by multiple testing (Holm method) between groups.

\section{Statistical analysis}

Descriptive statistics and simple analyses were carried out using the statistical package $\mathrm{R}$ version 2.4.1 (www. $\mathrm{r}$-project.org/). Apoptosis induction was analyzed by Welch's $t$-test. Antitumor effects were analyzed by the Bonferroni-Holm method. P-values of $<0.05$ were considered to be statistically significant.

\section{Results}

Crystal structure of $\left[\mathrm{PtCl}_{2}(\mathrm{~L})\right]$ and $\left[\mathrm{PdCl}_{2}(\mathrm{~L})\right]$

The crystal structures of $\left[\mathrm{PtCl}_{2}(\mathrm{~L})\right]$ and $\left[\mathrm{PdCl}_{2}(\mathrm{~L})\right]$ (Cambridge Crystallographic Data Center as supplementary publication no. CCDC-835397) show that each metal atom is surrounded by four donor atoms, two nitrogen atoms and two chloride ions, in a cis-configuration. As expected, the geometry around the metal center is approximately square planar (Figure 1). The pyranoid ring of the sugar unit adopts an unusual $\alpha-{ }^{4} C_{1}$ conformation. Thus, both complexes have similar structures.

\section{Conformational analysis of sugar units on $\left[\mathrm{PtCl}_{2}(\mathrm{~L})\right]$ and} $\left[\mathrm{PdCl}_{2}(\mathrm{~L})\right]$ by means of NMR measurements

${ }^{1} \mathrm{H}-\mathrm{NMR}$ and ${ }^{13} \mathrm{C}-\mathrm{NMR}$ spectra of the two complexes were obtained in DMF- $\mathrm{d}_{7} / \mathrm{D}_{2} \mathrm{O}$ and unambiguously assigned by ${ }^{1} \mathrm{H}_{-}{ }^{1} \mathrm{H}$ and ${ }^{13} \mathrm{C}_{-}{ }^{2} \mathrm{H}$ COSY two-dimensional NMR spectroscopy. Conformation of the sugar ring in both complexes was investigated by ${ }^{1} \mathrm{H}$-NMR spectroscopy in DMF- $\mathrm{d}_{7} / \mathrm{D}_{2} \mathrm{O}$ after $\mathrm{OH}$ proton exchange, which reveals signals originating from protons that are attached to the carbon atoms of the sugar unit. The vicinal proton-proton coupling constants for $\left[\mathrm{PtCl}_{2}(\mathrm{~L})\right]\left({ }^{3} J_{1,2}=\right.$ $\left.3.2,{ }^{3} J_{2,3}=11.2,{ }^{3} J_{3,4}=8.4,{ }^{3} J_{4,5}=10.0 \mathrm{~Hz}\right)$ and $\left[\mathrm{PdCl}_{2}\right.$ (L)] $\left({ }^{3} J_{1,2}=3.4,{ }^{3} J_{2,3}=11.2,{ }^{3} J_{3,4}=8.6,{ }^{3} J_{4,5}=10.0 \mathrm{~Hz}\right)$ correspond to $\alpha-{ }^{4} C_{1}$ conformations as observed in the $\mathrm{X}$-ray crystallography, indicating the structural similarity in the sugar unit in the solid and solution states.

\section{Genes up-regulated in CDDP-resistant gastric cancer sublines}

The 20-fold changes in gene expression for MKN45 (0) and MKN45 (CDDP) are presented in Table 1. Among 84 genes related to human cancer drug resistance and metabolism, 8 genes were significantly altered with fold changes larger than 20. Genes that were up-regulated by greater than 20-fold were ABCB1, APC, ATM, BRCA2 and $\mathrm{CDKN2A}$, whereas down-regulated genes were CYP2B6, CYP2C19 and PPARY.

\section{$\left[\mathrm{PdCl}_{2}(\mathrm{~L})\right]$ revealed minimum resistance to} CDDP-resistant gastric cancer cells

We investigated the cytotoxicity of CDDP, $\left[\mathrm{PtCl}_{2}(\mathrm{~L})\right]$, $\left[\mathrm{PdCl}_{2}(\mathrm{~L})\right], \mathrm{L}-\mathrm{OHP}$ and CABDA in the gastric cancer cell lines MKN28 (0), MKN28 (CDDP), MKN45 (0) and MKN45 (CDDP), and summarize the results in Table 2. In the parent cell lines (MKN28 (0) and MKN45 (0)), $\left[\mathrm{PtCl}_{2}(\mathrm{~L})\right]$ and $\left[\mathrm{PdCl}_{2}(\mathrm{~L})\right]$ exhibited lower cytotoxicity than CDDP and L-OHP, and higher cytotoxicity than CABDA. Resistance factor (RF) was calculated as the relative ratio of $\mathrm{IC}_{50}$ values in both cell lines (MKN28 (CDDP)/MKN28 (0) or MKN45 (CDDP)/MKN45 (0)).

\section{(A)}

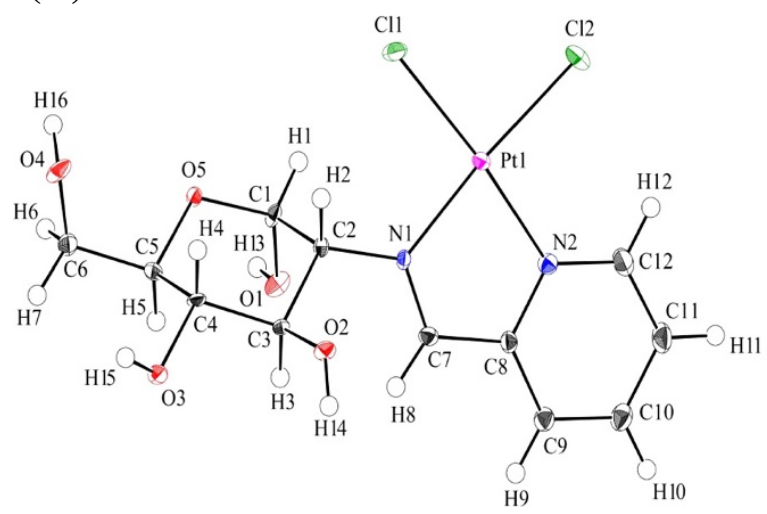

$\left[\mathrm{PtCl}_{2}(\mathrm{~L})\right]$
(B)

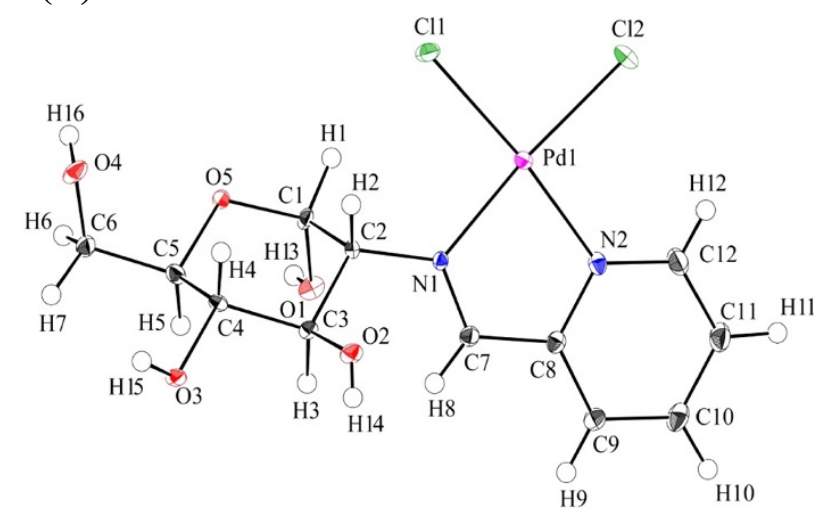

$\left[\mathrm{PdCl}_{2}(\mathrm{~L})\right]$

Figure 1 Structures of complexes used in this study. (A) Perspective drawing of $\left[\mathrm{PtCl}_{2}(\mathrm{~L})\right]$ with atomic numbering scheme in the crystal. Selected bond length ( $(\AA)$ and angles ( ${ }^{\circ}$ ), Pt(1)-Cl(1) 2.2985(8), Pt(1)-CI(2) 2.2922(8), Pt(1)-N(1) 2.016(3), Pt(1)-N(2) 2.006(3); Cl(1)-Pt(1)-Cl(2) 89.77(3), $\mathrm{Cl}(1)-\mathrm{Pt}(1)-\mathrm{N}(1)$ 94.84(7), $\mathrm{Cl}(2)-\mathrm{Pt}(1)-\mathrm{N}(2)$ 95.30(7), N(1)-Pt(1)-N(2) 80.14(10). (B) Perspective drawing of $\left[\mathrm{PdCl}_{2}\right.$ (L)] with atomic numbering scheme in the crystal. Selected bond length $(\AA)$ and angles $\left({ }^{(}\right), \operatorname{Pd}(1)-\mathrm{Cl}(1)$ 2.2940(8), $\mathrm{Pd}(1)-\mathrm{Cl}(2)$ 2.2832(8), $\mathrm{Pd}(1)-\mathrm{N}(1) 2.033(2), \operatorname{Pd}(1)-\mathrm{N}(2) 2.025(2) ; \mathrm{Cl}(1)-\mathrm{Pd}(1)-\mathrm{Cl}$ (2) 91.04(3), Cl(1)-Pd(1)-N(1) 94.02(7), Cl(2)-Pd(1)- N(2) 94.50(6), N(1)-Pd(1)-N(2) 80.49(8). 
Table 1 Expression profiles of genes related to human cancer drug resistance and metabolism showing at least 20-fold change in expression

\begin{tabular}{llll}
\hline Symbol & GenebankID & Incease & Gene name \\
\hline ABCB1 & NM_000927 & 122.73 & ABC20,CD243,CLCS,GP170,MDR1,MGC163296,P-GP,PGY1 \\
\hline APC & NM_000038 & 27.25 & BTPS2,DP2,DP2,5,DP3,GS \\
\hline ATM & NM_000051 & 27.35 & AT1,ATA,ATC,ATD,ATDC,ATE,DKFZp781A0353,MGC74674,TEL1,TELO1 \\
\hline BRCA2 & NM_000059 & 34.61 & BRCC2,BROVCA2,FACD,FAD,FAD1,FANCB,FANCD,FANCD1 \\
\hline CDKN2A & NM_000077 & 2689.53 & ARF,CDK41,CDKN2,CMM2,INK4,INK4a,MLM,MTS1,TP16,P14,Prop14ARF, \\
& p16,P16INK4,P16INK4a,P19 \\
\hline CYP2B6 & NM_000767 & CPB6,CYP2B,CYPIIB6,IIB1,P450 \\
\hline CYP2C19 & NM_000769 & -39.27 & CPCJ,CYP2C,P450C2C,P450IIC19 \\
\hline PPARG & NM_015869 & -145.20 & CIMT1,NR1C3,PPARG1,PPARG2,PPARgamma \\
\hline
\end{tabular}

Similarly to CABDA, cells treated with $\left[\mathrm{PtCl}_{2}(\mathrm{~L})\right]$ showed cross-resistance to CDDP. On the other hand, $\left[\mathrm{PdCl}_{2}(\mathrm{~L})\right]$ overcame cross-resistance to CDDP, similarly to L-OHP, although $\left[\mathrm{PdCl}_{2}(\mathrm{~L})\right]$ showed a lower degree of cross-resistance than L-OHP (Table 2).

$\left[\mathrm{PdCl}_{2}(\mathrm{~L})\right]$ induced apoptosis in CDDP-resistant gastric cancer cell lines

We examined apoptosis induction by CDDP, $\left[\mathrm{PtCl}_{2}(\mathrm{~L})\right]$, $\left[\mathrm{PdCl}_{2}(\mathrm{~L})\right], \mathrm{L}-\mathrm{OHP}$ and CABDA in the gastric cancer cell lines MKN45 (0) and MKN45 (CDDP) (Figure 2A). In the parental cell line (MKN45 (0)), all drugs tended to induce apoptosis in a dose-dependent manner. In the CDDP-resistant subline (MKN45 (CDDP)), induction of apoptosis by CDDP, CABDA and $\left[\mathrm{PtCl}_{2}(\mathrm{~L})\right]$ was lower than in the parental cell line. On the other hand, $\left[\mathrm{PdCl}_{2}\right.$ (L)] and L-OHP maintained apoptosis induction against CDDP-resistant gastric cancer cells.

Table 2 In vitro cytotoxicity assay in CDDP-sensitive and -resistant gastric cancer cell lines

\begin{tabular}{llcc}
\hline MKN28 & Resistance factor & \multicolumn{2}{c}{ IC50 $(\boldsymbol{\mu M})$} \\
\cline { 3 - 4 } & & MKN28(0) & MKN28(CDDP) \\
\hline$[\mathrm{PdCl} 2(\mathrm{~L})]$ & 1.02 & $48.9 \pm 4.0$ & $80.8 \pm 6.6$ \\
\hline $\mathrm{L}-\mathrm{OHP}$ & 1.19 & $11.7 \pm 27.1$ & $283.9 \pm 19.3$ \\
\hline$[\mathrm{PtCl}(\mathrm{L})]$ & 2.54 & $19.4 \pm 2.4$ & $65.4 \pm 4.6$ \\
\hline $\mathrm{CDDP}$ & 3.37 & $202.9 \pm 17.2$ & $878.3 \pm 34.1$ \\
\hline $\mathrm{CABDA}$ & 4.33 & \multicolumn{2}{c}{ IC50( $\mathbf{\mu M})$} \\
\hline MKN45 & Resistance factor & $\mathbf{M K N 4 5 ( 0 )}$ & $\mathbf{M K N 4 5 ( C D D P )}$ \\
\hline$[\mathrm{PdCl} 2(\mathrm{~L})]$ & 1.14 & $61.2 \pm 6.8$ & $69.7 \pm 4.1$ \\
\hline $\mathrm{L}-\mathrm{OHP}$ & 1.3 & $27.3 \pm 1.1$ & $35.6 \pm 6.7$ \\
\hline$[\mathrm{PtCl} 2(\mathrm{~L})]$ & 2.18 & $129.5 \pm 14.8$ & $282.6 \pm 34.5$ \\
\hline $\mathrm{CDDP}$ & 3.27 & $23.5 \pm 2.2$ & $77.0 \pm 8.5$ \\
\hline $\mathrm{CABDA}$ & 3.42 & $152.8 \pm 3.7$ & $522.0 \pm 27.4$ \\
\hline
\end{tabular}

$\left[\mathrm{PdCl}_{2}(\mathrm{~L})\right]$ induced DNA double-strand breaks in CDDP-resistant gastric cancer cells

Cells were labeled with an antibody against phosphorylated histone $\mathrm{H} 2 \mathrm{AX}(\gamma-\mathrm{H} 2 \mathrm{AX})$, which detects doublestrand breaks caused by drugs such as CDDP [19]. We used Western blotting for evaluation of $\gamma-\mathrm{H} 2 \mathrm{AX}$ protein expression by CDDP and $\left[\mathrm{PdCl}_{2}(\mathrm{~L})\right]$ in the gastric cancer cell lines MKN45 (0) and MKN45 (CDDP). In the parental cell line (MKN45 (0)) treated with CDDP or $\left[\mathrm{PdCl}_{2}(\mathrm{~L})\right], \gamma-\mathrm{H} 2 \mathrm{AX}$ protein levels increased and were the same by 24 and $48 \mathrm{~h}$ after treatment. In the CDDPresistant subline (MKN45 (CDDP)), $\gamma$-H2AX protein levels increased with $\left[\mathrm{PdCl}_{2}(\mathrm{~L})\right]$, but did not increase with CDDP (Figure 2B). These results indicated that $\left[\mathrm{PdCl}_{2}(\mathrm{~L})\right]$, but not CDDP induced DNA double-strand breaks in CDDP-resistant gastric cancer cells.

$\left[\mathrm{PdCl}_{2}(\mathrm{~L})\right]$ significantly suppressed CDDP-resistant gastric cancer cell proliferation

We examined the effects of CDDP, $\left[\mathrm{PtCl}_{2}(\mathrm{~L})\right]$ and $\left[\mathrm{PdCl}_{2}(\mathrm{~L})\right]$ on xenograft tumor models established by subcutaneously implanting the gastric cancer cell lines MKN45 (0) and MKN45 (CDDP). At 7 days after tumor inoculation, mice were given an intra-peritoneal injection of CDDP, $\left[\mathrm{PtCl}_{2}(\mathrm{~L})\right]$ or $\left[\mathrm{PdCl}_{2}(\mathrm{~L})\right]$ at a dose of $40 \mu \mathrm{mol} / \mathrm{kg}$. In MKN45 (0) nude mice, CDDP, $\left[\mathrm{PtCl}_{2}\right.$ $(\mathrm{L})]$ and $\left[\mathrm{PdCl}_{2}(\mathrm{~L})\right]$ suppressed tumor growth significantly as compared to controls $(\mathrm{p}<0.01)$. In MKN45 (CDDP) nude mice, $\left[\mathrm{PdCl}_{2}(\mathrm{~L})\right]$ suppressed tumor growth significantly $(\mathrm{p}<0.01)$ as compared to CDDP, but $\left[\mathrm{PtCl}_{2}\right.$ (L)] did not (Figure 3). None of the therapies had any obvious side effects, such as diarrhea or weight loss (data not shown).

\section{Discussion}

$\left[\mathrm{PtCl}_{2}(\mathrm{~L})\right]$ and $\left[\mathrm{PdCl}_{2}(\mathrm{~L})\right]$ were developed as antitumor drugs with sugar conjugated ligands, and were expected to have a number of advantages, including significant reductions in side effects, improved water solubility, and 


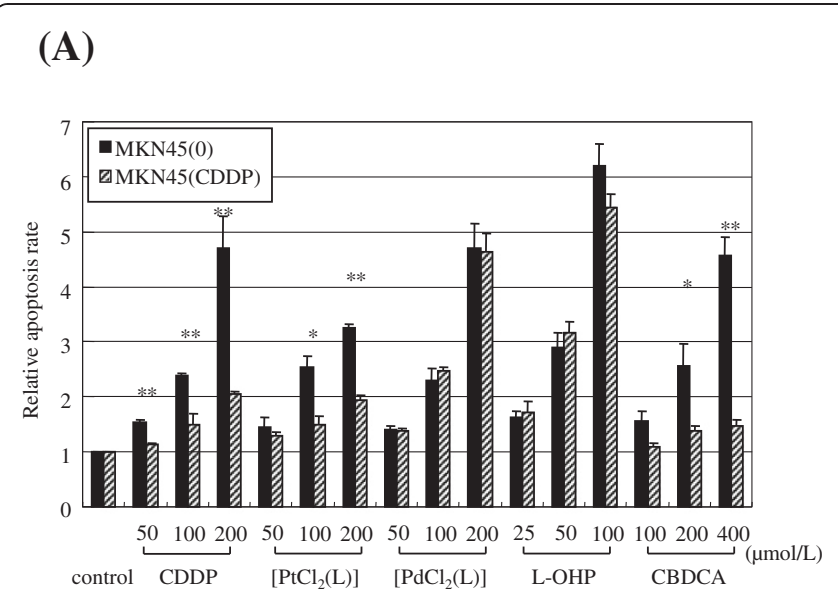

(B)
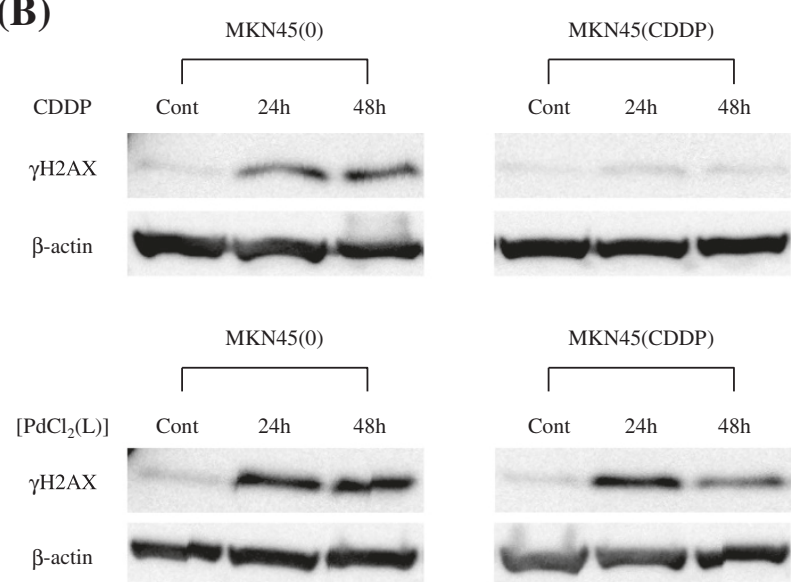

Figure 2 Investigation of cytotoxicity mechanism of $\left[\mathrm{PtCl}_{\mathbf{2}}(\mathbf{L})\right]$ and $\left[\mathrm{PdCl}_{\mathbf{2}}(\mathbf{L})\right]$. (A) $\left[\mathrm{PdCl}_{2}(\mathrm{~L})\right]$ induced apoptosis on CDDP-resistant gastric cancer cell lines. Apoptosis was assessed by analyzing activation of caspase-3 and caspase-7. Mean of three independent experiments in triplicate; bars, SE. Values for apoptosis of cells in FBS alone were used as controls. Significance was determined by Welch's $t$-test. ${ }^{*}, P<0.05,{ }^{* *}, P<0.01$ relative to parental cell line. (B) $\left[\mathrm{PdCl}_{2}(\mathrm{~L})\right]$ induced DNA double-strand breaks in CDDP-resistant gastric cancer cells. Cells were labeled with antibody against phosphorylated histone $\mathrm{H} 2 \mathrm{AX}(\mathrm{Y}-\mathrm{H} 2 \mathrm{AX})$, which detects double-strand breaks caused by drugs such as CDDP. An evaluation of $\mathrm{Y}$-H2AX protein expression was investigated by Western blotting at 24 or $48 \mathrm{~h}$ after treatment.

greater cellular uptake. These complexes were very easily prepared in good yields by one-pot reaction of Pt or Pd salts, amino sugar and pyridine aldehyde derivative without isolation of Schiff base ligand, and were characterized by X-ray crystallography and ${ }^{1} \mathrm{H}$ - and ${ }^{13} \mathrm{C}-\mathrm{NMR}$ spectra. One-pot reaction is a strategy to improve the efficiency of a chemical reaction whereby a reactant is subjected to successive chemical reactions. This saves time and resources by avoiding lengthy separation processes and purification of the intermediate chemical compounds while increasing chemical yield.
In this report, we found that gastric cancer cell lines adapted to growth in the presence of $10 \mu \mathrm{mol} / \mathrm{L}$ CDDP (MKN45 (CDDP)) showed enhanced ABCB1 and CDKN2A expression as compared with their CDDPsensitive parental cell lines (MKN45 (0)) (Table 1). Prolongation of the cell cycle at the G1-S transition allows for DNA repair to occur. It is therefore unsurprising that growth arrest mediated by CDKN2A is able to enhance resistance to drugs whose mechanism of action is dependent on DNA damage, such as CDDP [20]. ABCB1 is the most extensively studied $A B C$ transporter [21].
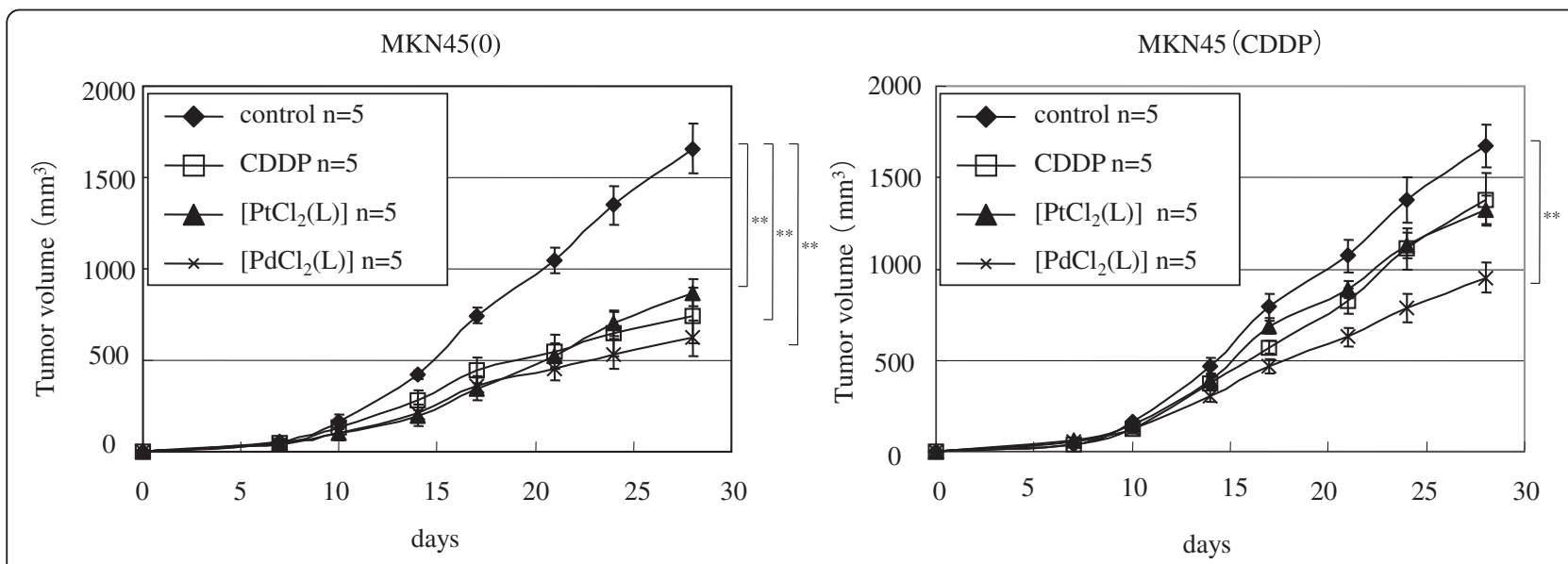

Figure $3\left[\mathrm{PdCl}_{2}(\mathrm{~L})\right]$ significantly suppressed CDDP-resistant gastric cancer cell proliferation in xenograft model. Cells were inoculated in dorsal skin at a concentration of $3 \times 10^{6}$ gastric cancer cells (MKN45 (0), MKN45 (CDDP)) in $200 \mu \mathrm{L}$ of PBS. At 7 days after tumor inoculation, tumor-bearing mice were given intraperitoneal injection of CDDP, $\left[\mathrm{PtCl}_{2}(\mathrm{~L})\right]$ or $\left[\mathrm{PdCl}_{2}(\mathrm{~L})\right]$ at a dose of $40 \mu \mathrm{mol} / \mathrm{kg}(\mathrm{n}=5$ for each). Tumor volumes were monitored for 28 days in control mice (no treatment), and mice treated with $\mathrm{CDDP},\left[\mathrm{PtCl}_{2}(\mathrm{~L})\right]$ or $\left[\mathrm{PdCl}_{2}(\mathrm{~L})\right]$. Data are means $\pm \mathrm{SE}$. Significance was determined by the Bonferroni-Holm method. ${ }^{*}, \mathrm{P}<0.01$ relative to controls. 
The expression of P-glycoprotein ABCB1 is implicated in multidrug resistance (MDR). MDR proteins confer drug resistance by reducing intracellular drug accumulation due to active efflux of drugs [22,23]. The CDDP-resistant cell line (MKN45 (CDDP)) was useful for studying the resistance mechanisms of CDDP and for studying the effects of other anticancer drugs for gastric cancer under CDDP resistance.

Many experiments have been performed in order to develop new anti-cancer drugs that show preferential accumulation within the target tumor tissue for various active targeting approaches, such as liposomes [24], polymer microspheres [25-27] and nanoparticles [28-31]. Our results indicate that the glucose-linked anticancer drug is a useful drug delivery system for accumulation in the target tumor.

In order to circumvent CDDP resistance, significant amounts of work have been devoted to preparing anticancer complexes, including amine $\mathrm{Pt}$ complexes [32,33], diamine Pt complexes [34,35], trans-Pt complexes [36-38], multinuclear Pt complexes [39-41] and Pt (IV) coordination complexes [42-44]. Progress in the field of anticancer chemistry of Pd-based transition metal complexes has been reviewed [45]. $\left[\mathrm{PdCl}_{2}(\mathrm{~L})\right]$ and $\mathrm{L}-\mathrm{OHP}$ overcame cross-resistance to CDDP, although $\left[\mathrm{PdCl}_{2}(\mathrm{~L})\right]$ showed a lower degree of cross-resistance than L-OHP (Table 2). The cytotoxicity of L-OHP in CDDP-resistant cell lines has been considered to be due to the differences of DNA damage and/or recognition processes between CDDP and L-OHP [46]. The DNA damage caused by Pd (II) compounds is reportedly processed in a different manner from that induced by Pt (II) complexes [47]. In the CDDP-resistant subline (MKN45 $(\mathrm{CDDP})), \quad\left[\mathrm{PdCl}_{2}(\mathrm{~L})\right]$ showed significantly higher antitumor effects in vitro (Table 2 ) and in vivo (Figure 3 ) as compared with CDDP and $\left[\mathrm{PtCl}_{2}(\mathrm{~L})\right]$. Apoptosis by $\left[\mathrm{PdCl}_{2}(\mathrm{~L})\right]$ did not decrease when compared with parental cells, although apoptosis induced by $\left[\mathrm{PtCl}_{2}(\mathrm{~L})\right]$ decreased (Figure 2A). These results indicate that the resistance mechanism of Pd (II) complexes might be different from those of Pt (II) complexes.

Phosphorylation of histone $\mathrm{H} 2 \mathrm{AX}(\gamma \mathrm{H} 2 \mathrm{AX})$ has been used as an indicator of exposure to a variety of DNAdamaging agents such as ionizing radiation [48], gemcitabine [49], topotecan [50], etoposide, bleomycin, and doxorubicin [51]. The stimulus for $\gamma \mathrm{H} 2 \mathrm{AX}$ formation after CDDP treatment is replication fork collapse and subsequent double-strand break formation at sites of inter-strand cross-links [52,53] immediately after formation of double-strand breaks $[52,54]$. The present results revealed that $\left[\mathrm{PdCl}_{2}(\mathrm{~L})\right]$ induced DNA double-strand breaks in CDDP-resistant gastric cancer cells in which CDDP could not induce DNA double-strand breaks (Figure 2B).

\section{Conclusion}

We demonstrated that a new glycoconjugated Pt (II) complex, $\left[\mathrm{PtCl}_{2}\right.$ (L)], and a new glycoconjugated Pd (II) complex, $\left[\mathrm{PdCl}_{2}(\mathrm{~L})\right]$, showed significant antitumor effects in CDDP-sensitive gastric cancer and executed their biological effects by inducing apoptosis. In addition, $\left[\mathrm{PdCl}_{2}(\mathrm{~L})\right]$ overcame cross-resistance to CDDP in CDDP-resistant gastric cancer, while $\left[\mathrm{PtCl}_{2}(\mathrm{~L})\right]$ did not. When compared with L-OHP, $\left[\mathrm{PdCl}_{2}(\mathrm{~L})\right]$ showed a lower degree of cross-resistance to CDDP and $\left[\mathrm{PdCl}_{2}\right.$ (L)] is speculated to be less toxic to the kidney than $\mathrm{Pt}$ complexes such as L-OHP and CDDP. Furthermore, glucose conjugation may increase drug solubility and tumor selectivity. From these findings, we conclude that $\left[\mathrm{PdCl}_{2}\right.$ (L)] is a potentially useful antitumor drug for CDDPresistant gastric cancer.

\section{Competing interests}

All the authors declare that there is no conflict of interest.

\section{Authors' contributions}

Conception and design, MT and HK; Acquisition of data, MT; Analysis and interpretation of data, MT and HK; Drafting of the manuscript, MT and HK; Revising it critically for important intellectual content, SY, HO and KK; Final approval of the version to be published, HK and TJ; General supervision of research group, TJ. All authors read and approved the final manuscript.

\section{Acknowledgements}

We are grateful to Dr. Kimiko Hasegawa at RIGAKU for her helpful X-ray crystallographic analysis and Yukimi Ito at Nagoya City University Graduate School of Medical Sciences for technical assistance. This work was financially supported in part by a Grant-in-Aid for Scientific Research from the Ministry of Education, Culture, Sports, Science and Technology (MEXT) of Japan, the Japan-German exchange program supported by the Japan Society for the Promotion of Science (JSPS), a Grant-in-Aid from Kyoto University for Young Scientists and the San-EiGen Foundation for Chemical Research. We would also like to thank Yukimi Ito for technical assistance.

\section{Financial support}

This study was supported by a Grant-in-Aid for Scientific Research from the Ministry of Education, Culture, Sports, Science and Technology (MEXT) of Japan, the Japan-German exchange program supported by the Japan Society for the Promotion of Science (JSPS), a Grant-in-Aid from Kyoto University for Young Scientists, and the San-EiGen Foundation for Chemical Research.

\section{Author details}

${ }^{1}$ Departments of Gastroenterology and Metabolism, Nagoya City University Graduate School of Medical Sciences, Kawasumi, Mizuho-cho, Mizuho-ku 467-8601, Nagoya, Japan. ${ }^{2}$ Graduate School of Materials Science, Nara Institute of Science and Technology, 8916-5 Takayama, Ikoma, Nara, 630-0192, Japan. ${ }^{3}$ Office of Society-Academia Collaboration for Innovation, Kyoto University, Katsura, Nishikyo-ku, Kyoto, Japan. ${ }^{4}$ Department of Industrial Chemistry, Kinki Polytechnic College, 1778 Inaba-cho, Kishiwada, Osaka 596-0103, Japan. ${ }^{5}$ Department of Chemistry, Okayama University of Science, 1-1Ridai-cho, Kita-ku 700-0005, Okayama, Japan.

Received: 23 July 2012 Accepted: 8 May 2013 Published: 14 May 2013

\section{References}

1. Hainsworth JD, Johnson DH, Greco FA: Cisplatin-based combination chemotherapy in the treatment of poorly differentiated carcinoma and poorly differentiated adenocarcinoma of unknown primary site: results of a 12-year experience. J Clin Oncol 1992, 10(6):912-922.

2. Koizumi W, Narahara H, Hara T, Takagane A, Akiya T, Takagi M, Miyashita K, Nishizaki T, Kobayashi O, Takiyama W, Toh Y, Nagaie T, Takagi S, Yamamura 
Y, Yanaoka K, Orita H, Takeuchi M: S-1 plus cisplatin versus S-1 alone for first-line treatment of advanced gastric cancer (SPIRITS trial): a phase III trial. Lancet Oncol 2008, 9(3):215-221.

3. Rennicke A, Voigt W, Mueller T, Fruehauf A, Schmoll HJ, Beyer C, Dempke W: Resistance mechanisms following cisplatin and oxaliplatin treatment of the human teratocarcinoma cell line 2102EP. Anticancer Res 2005, 25(2A):1147-1155.

4. Timmer-Bosscha $\mathrm{H}$, Mulder NH, De Vries EG: Modulation of cisdiamminedichloroplatinum(II) resistance: a review. Br J Cancer 1992, 66(2):227-238.

5. Kartalou M, Essigmann JM: Mechanisms of resistance to cisplatin. Mutat Res 2001, 478(1-2):23-43.

6. Hall MD, Okabe M, Shen DW, Liang XJ, Gottesman MM: The role of cellular accumulation in determining sensitivity to platinum-based chemotherapy. Annu Rev Pharmacol Toxicol 2008, 48:495-535.

7. Brabec V, Kasparkova J: Modifications of DNA by platinum complexes. Relation to resistance of tumors to platinum antitumor drugs. Drug Resist Updat 2005, 8(3):131-146.

8. Florea AM, Busselberg D: Anti-cancer drugs interfere with intracellular calcium signaling. NeuroToxicology 2009, 30(5):803-810.

9. Torigoe $T$, Izumi H, Ishiguchi H, Yoshida $Y$, Tanabe M, Yoshida T, Igarashi T, Niina I, Wakasugi T, Imaizumi T, Momii Y, Kuwano M, Kohno K: Cisplatin resistance and transcription factors. Curr Med Chem Anticancer Agents 2005, 5(1):15-27.

10. Xie XK, Yang DS, Ye ZM, Tao HM: Enhancement effect of adenovirusmediated antisense c-myc and caffeine on the cytotoxicity of cisplatin in osteosarcoma cell lines. Chemotherapy 2009, 55(6):433-440.

11. Wang Z, Xu B, Lin D, Tan W, Leaw S, Hong X, Hu X: XRCC1 polymorphisms and severe toxicity in lung cancer patients treated with cisplatin-based chemotherapy in Chinese population. Lung Cancer 2008, 62(1):99-104

12. Jordan P, Carmo-Fonseca M: Molecular mechanisms involved in cisplatin cytotoxicity. Cell Mol Life Sci 2000, 57(8-9):1229-1235.

13. Warburg O: On the origin of cancer cells. Science 1956, 123(3191):309-314.

14. Hirohara S, Obata M, Alitomo H, Sharyo K, Ando T, Tanihara M, Yano S: Synthesis, photophysical properties and sugar-dependent in vitro photocytotoxicity of pyrrolidine-fused chlorins bearing S-glycosides. J Photochem Photobiol B 2009, 97(1):22-33.

15. Tanaka M, Kataoka H, Mabuchi M, Sakuma S, Takahashi S, Tujii R, Akashi H, Ohi H, Yano S, Morita A, Joh T: Anticancer effects of novel photodynamic therapy with glycoconjugated chlorin for gastric and colon cancer. Anticancer Res 2011, 31(3):763-769.

16. Brudzinska I, Mikata Y, Obata M, Ohtsuki C, Yano S: Synthesis, structural characterization, and antitumor activity of palladium(II) complexes containing a sugar unit. Bioorg Med Chem Lett 2004, 14(10):2533-2536.

17. Dallavalle F, Gaccioli F, Franchi-Gazzola R, Lanfranchi M, Marchio L, Pellinghelli MA, Tegoni M: Synthesis, molecular structure, solution equilibrium, and antiproliferative activity of thioxotriazoline and thioxotriazole complexes of copper II and palladium II. J Inorg Biochem 2002, 92(2):95-104.

18. Divsalar A, Bagheri MJ, Saboury AA, Mansoori-Torshizi H, Amani M: Investigation on the interaction of newly designed anticancer $\mathrm{Pd}(\mathrm{II})$ complexes with different aliphatic tails and human serum albumin. J Phys Chem B 2009, 113(42):14035-14042.

19. Foster ER, Downs JA: Histone H2A phosphorylation in DNA double-strand break repair. FEBS J 2005, 272(13):3231-3240.

20. Grim J, D'Amico A, Frizelle S, Zhou J, Kratzke RA, Curiel DT: Adenovirusmediated delivery of p16 to p16-deficient human bladder cancer cells confers chemoresistance to cisplatin and paclitaxel. Clin Cancer Res 1997, 3(12 Pt 1):2415-2423

21. Li YT, Chua MJ, Kunnath AP, Chowdhury EH: Reversing multidrug resistance in breast cancer cells by silencing $A B C$ transporter genes with nanoparticle-facilitated delivery of target siRNAs. Int J Nanomedicine 2012, 7:2473-2481.

22. Cole SP, Sparks KE, Fraser K, Loe DW, Grant CE, Wilson GM, Deeley RG: Pharmacological characterization of multidrug resistant MRP-transfected human tumor cells. Cancer Res 1994, 54(22):5902-5910.

23. Theou N, Gil S, Devocelle A, Julie C, Lavergne-Slove A, Beauchet A, Callard P, Farinotti R, Le Cesne A, Lemoine A, Faivre-Bonhomme L, Emile JF: Multidrug resistance proteins in gastrointestinal stromal tumors: sitedependent expression and initial response to imatinib. Clin Cancer Res 2005, 11(21):7593-7598.
24. Vicent MJ, Duncan R: Polymer conjugates: nanosized medicines for treating cancer. Trends Biotechnol 2006, 24(1):39-47.

25. Liu Z, Ballinger JR, Rauth AM, Bendayan R, Wu XY: Delivery of an anticancer drug and a chemosensitizer to murine breast sarcoma by intratumoral injection of sulfopropyl dextran microspheres. J Pharm Pharmacol 2003, 55(8):1063-1073.

26. Lin R, Shi Ng L, Wang CH: In vitro study of anticancer drug doxorubicin in PLGA-based microparticles. Biomaterials 2005, 26(21):4476-4485.

27. Foger F, Noonpakdee W, Loretz B, Joojuntr S, Salvenmoser W, Thaler M, BernkopSchnurch A: Inhibition of malarial topoisomerase II in Plasmodium falciparum by antisense nanoparticles. Int J Pharm 2006, 319(1-2):139-146.

28. Ambruosi A, Khalansky AS, Yamamoto H, Gelperina SE, Begley DJ, Kreuter J: Biodistribution of polysorbate 80-coated doxorubicin-loaded [14C]-poly (butyl cyanoacrylate) nanoparticles after intravenous administration to glioblastoma-bearing rats. J Drug Target 2006, 14(2):97-105.

29. Dong Y, Feng SS: Nanoparticles of poly(D, L-lactide)/methoxy poly (ethylene glycol)-poly(D, L-lactide) blends for controlled release of paclitaxel. J Biomed Mater Res A 2006, 78(1):12-19.

30. Farokhzad OC, Karp JM, Langer R: Nanoparticle-aptamer bioconjugates for cancer targeting. Expert Opin Drug Deliv 2006, 3(3):311-324.

31. Cheng $X$, Kuhn L: Chemotherapy drug delivery from calcium phosphate nanoparticles. Int J Nanomedicine 2007, 2(4):667-674.

32. Raynaud FI, Boxall FE, Goddard PM, Valenti M, Jones M, Murrer BA, Abrams M: Kelland LR: cis-Amminedichloro(2-methylpyridine) platinum(II) (AMD473), a novel sterically hindered platinum complex: in vivo activity, toxicology, and pharmacokinetics in mice. Clin Cancer Res 1997, 3(11):2063-2074.

33. Yoshida M, Khokhar AR, Siddik ZH: Cytotoxicity and tolerance to DNA adducts of alicyclic mixed amine platinum(II) homologs in tumor models sensitive and resistant to cisplatin or tetraplatin. Oncol Rep 1998 5(5):1281-1287.

34. Paul AK, Srivastava TS, Chavan SJ, Chitnis MP, Desai S, Rao KK: Synthesis, characterization, cytotoxic, and DNA binding studies of some platinum (II) complexes of 1,2-diamine and alpha-diimine with 2pyridinecarboxylate anion. J Inorg Biochem 1996, 61(3):179-196.

35. Monti E, Gariboldi M, Maiocchi A, Marengo E, Cassino C, Gabano E, Osella D: Cytotoxicity of cis-platinum(II) conjugate models. The effect of chelating arms and leaving groups on cytotoxicity: a quantitative structure-activity relationship approach. J Med Chem 2005, 48(3):857-866.

36. Bierbach U, Qu Y, Hambley TW, Peroutka J, Nguyen HL, Doedee M, Farrell N: Synthesis, Structure, Biological Activity, and DNA Binding of Platinum(II) Complexes of the Type trans-[PtCl(2)(NH(3))L] (L = Planar Nitrogen Base). Effect of $L$ and Cis/Trans Isomerism on Sequence Specificity and Unwinding Properties Observed in Globally Platinated DNA. Inorg Chem 1999, 38(15):3535-3542.

37. Ali MS, Khan SR, Ojima H, Guzman IY, Whitmire KH, Siddik ZH, Khokhar AR Model platinum nucleobase and nucleoside complexes and antitumor activity: X-ray crystal structure of PtIV(trans-1R,2R-diaminocyclohexane) trans-(acetate)2(9-ethylguanine)Cl]NO 3.H2O. J Inorg Biochem 2005, 99(3):795-804

38. Coluccia M, Natile G: Trans-platinum complexes in cancer therapy. Anticancer Agents Med Chem 2007, 7(1):111-123.

39. Manzotti C, Pratesi G, Menta E, Di Domenico R, Cavalletti E, Fiebig HH, Kelland LR, Farrell N, Polizzi D, Supino R, Pezzoni G, Zunino F: BBR 3464: a novel triplatinum complex, exhibiting a preclinical profile of antitumor efficacy different from cisplatin. Clin Cancer Res 2000, 6(7):2626-2634

40. Komeda S, Kalayda GV, Lutz M, Spek AL, Yamanaka Y, Sato T, Chikuma M, Reedijk J: New isomeric azine-bridged dinuclear platinum(II) complexes circumvent cross-resistance to cisplatin. J Med Chem 2003, 46(7):1210-1219.

41. Zhu J, Zhao Y, Zhu Y, Wu Z, Lin M, He W, Wang Y, Chen G, Dong L, Zhang J, Lu Y, Guo Z: DNA cross-linking patterns induced by an antitumoractive trinuclear platinum complex and comparison with its dinuclear analogue. Chemistry 2009, 15(21):5245-5253.

42. Kelland LR, Murrer BA, Abel G, Giandomenico CM, Mistry P, Harrap KR: Ammine/amine platinum(IV) dicarboxylates: a novel class of platinum complex exhibiting selective cytotoxicity to intrinsically cisplatin-resistant human ovarian carcinoma cell lines. Cancer Res 1992, 52(4):822-828.

43. Yoshida M, Khokhar AR, Siddik ZH: Axial ligands and alicyclic ring size modulate the activity and biochemical pharmacology of ammine/cycloalkylamineplatinum(IV) complexes in tumor cells resistant to cis-diamminedichloroplatinum (II) or trans-1R,2R-1S,2S-diaminocyclohexanetetrachloroplatinum(IV). Cancer Res 1994, 54(17):4691-4697. 
44. Kelland LR, Barnard CF, Mellish KJ, Jones M, Goddard PM, Valenti M, Bryant A, Murrer BA, Harrap KR: A novel trans-platinum coordination complex possessing in vitro and in vivo antitumor activity. Cancer Res 1994, 54(21):5618-5622.

45. Caires AC: Recent advances involving palladium (II) complexes for the cancer therapy. Anticancer Agents Med Chem 2007, 7(5):484-491.

46. Chaney SG, Campbell SL, Bassett E, Wu Y: Recognition and processing of cisplatin- and oxaliplatin-DNA adducts. Crit Rev Oncol Hematol 2005, 53(1):3-11.

47. Kruszewski M, Bouzyk E, Oldak T, Samochocka K, Fuks L, Lewandowski W, Fokt I, Priebe W: Differential toxic effect of cis-platinum(II) and palladium (II) chlorides complexed with methyl 3,4-diamine-2,3,4,6-tetradeoxyalpha-L-lyxo-hexopyranoside in mouse lymphoma cell lines differing in DSB and NER repair ability. Teratog Carcinog Mutagen 2003, Suppl 1:1-11.

48. Tanaka T, Huang X, Halicka HD, Zhao H, Traganos F, Albino AP, Dai W, Darzynkiewicz Z: Cytometry of ATM activation and histone H2AX phosphorylation to estimate extent of DNA damage induced by exogenous agents. Cytometry A 2007, 71(9):648-661.

49. Ewald B, Sampath D, Plunkett W: H2AX phosphorylation marks gemcitabine-induced stalled replication forks and their collapse upon S-phase checkpoint abrogation. Mol Cancer Ther 2007, 6(4):1239-1248.

50. Huang X, Okafuji M, Traganos F, Luther E, Holden E, Darzynkiewicz Z Assessment of histone $\mathrm{H} 2 \mathrm{AX}$ phosphorylation induced by DNA topoisomerase I and II inhibitors topotecan and mitoxantrone and by the DNA cross-linking agent cisplatin. Cytometry A 2004, 58(2):99-110.

51. Banath JP, Olive PL: Expression of phosphorylated histone H2AX as a surrogate of cell killing by drugs that create DNA double-strand breaks. Cancer Res 2003, 63(15):4347-4350.

52. Olive PL, Banath JP: Kinetics of H2AX phosphorylation after exposure to cisplatin. Cytometry B Clin Cytom 2009, 76(2):79-90

53. Niedernhofer $L$, Odijk H, Budzowska M, Van Drunen E, Maas A, Theil AF, De Wit J, Jaspers NG, Beverloo HB, Hoeijmakers JH, Kanaar R: The structurespecific endonuclease Ercc1-Xpf is required to resolve DNA interstrand cross-link-induced double-strand breaks. Mol Cell Biol 2004 24(13):5776-5787.

54. Banuelos CA, Banath JP, Kim JY, Aquino-Parsons C, Olive PL: gammaH2AX expression in tumors exposed to cisplatin and fractionated irradiation. Clin Cancer Res 2009, 15(10):3344-3353.

doi:10.1186/1471-2407-13-237

Cite this article as: Tanaka et al.: Anti-cancer effects of newly developed chemotherapeutic agent, glycoconjugated palladium (II) complex, against cisplatin-resistant gastric cancer cells. BMC Cancer 2013 13:237.

\section{Submit your next manuscript to BioMed Central and take full advantage of:}

- Convenient online submission

- Thorough peer review

- No space constraints or color figure charges

- Immediate publication on acceptance

- Inclusion in PubMed, CAS, Scopus and Google Scholar

- Research which is freely available for redistribution

Submit your manuscript at www.biomedcentral.com/submit
Biomed Central 